\title{
The Relationship between Listening Strategies Used by Egyptian EFL College Sophomores and Their Listening Comprehension and Self-Efficacy
}

\author{
Hassan M. Kassem ${ }^{1}$ \\ ${ }^{1}$ Tanta University, Egypt \& Shaqra University, Saudi Arabia \\ Correspondence: Hassan Kassem, Faculty of Education, Tanta University, El-Gish St., Tanta, Egypt. E-mail: \\ hkassem2007@hotmail.com
}

Received: October 19, 2014 Accepted: November 21, 2014 Online Published: January 20, 2015

doi:10.5539/elt.v8n2p153 URL: http://dx.doi.org/10.5539/elt.v8n2p153

\begin{abstract}
The present study explored listening strategy use among a group of Egyptian EFL college sophomores $(\mathrm{N}=84)$. More specifically, it aimed to identify 1) the strategies used more often by participants, 2) the relationship between listening strategy use, and listening comprehension and self-efficacy, and 3) differences in listening comprehension and self-efficacy between students with high and low strategy frequency. A Listening Comprehension Test adapted from paper-based Longman TOEFL test was used to assess participants' listening comprehension. Listening strategy use and self-efficacy about listening were assessed by two instruments developed by the researcher based on relevant literature: a Listening Strategy Questionnaire and a Self-efficacy Questionnaire. Descriptive statistics, correlation coefficients and t-test for independent samples were computed to answer the research questions. Results revealed that cognitive strategies were used more often by participants, followed by metacognitive and socioaffective strategies. Listening strategies correlated significantly with both listening comprehension and self-efficacy. Except for socioaffective strategies, participants with high frequent overall strategy use, cognitive strategies and metacognitive strategies outperformed their counterparts with low frequency in both listening comprehension and self-efficacy. Implications and suggestions for further research are reported.
\end{abstract}

Keywords: listening strategies, listening comprehension, listening self-efficacy, EFL, English sophomores

\section{Introduction}

Being the two main channels of language input, reading and listening play a vital role in FL learning. The more learners read and listen, the more they are exposed to language. This exposure is what leads to language acquisition (Krashen, 1985; Peterson, 2001). It is therefore safe to say that language learning is contingent on how much learners read and listen to the FL. Listening is even of more importance to language development than reading because it is the most frequently used language skill (Ferris, 1998; Vogely, 1998; Morley, 1999). Through listening, language learners internalize linguistic information without which they cannot produce language (Brown, 2001). Listening is also crucial to the development of other language skills, especially speaking (Rost, 2002).

For FL learners, listening is more demanding than reading. This demanding nature is evident in Purdy's (1997, p. 8) definition of listening as "active and dynamic process of attending, perceiving, interpreting, remembering, and responding to the expressed (verbal and nonverbal) needs, concerns, and information offered by other human beings." The ability to comprehend spoken language entails complex, instant and simultaneous processing of different types of information. To comprehend spoken language, one needs to coordinate sounds, vocabulary, grammatical structures, and background knowledge (Vandergrift, 1999). Many scholars therefore assert the difficult nature of listening (Vogely, 1999; Gonen, 2009). Empirically, several factors have been found to contribute to the problematic nature of FL listening (e.g. Underwood, 1989; Long, 1990; Griffths, 1992; Higgins, 1995; Zhao, 1997; Vogely, 1998; Goh, 2000). For instance, Underwood (1989) identified seven problematic areas that may hinder listening comprehension: lack of control over the speed of delivery, lack of repetition in the listening material, limited vocabulary, failure to recognize discourse markers, lack of contextual knowledge, inability to concentrate in a FL, and established learning habits such as a wish to understand every word. 
Listening comprehension entails online processing (Gonen, 2009) of linguistic and background information, and coping with the uncontrollable speed of delivery. It therefore involves a great deal of mental processes (Vandergrift, 1999). This makes listening anxiety provoking (Vogely, 1999; Gonen, 2009), especially for FL learners whose limited linguistic proficiency worsens the situation. Another important cause of FL listening anxiety is what Joiner (1986) calls negative listening self-concept. This negative self-concept is another face of anxiety and lack of self-efficacy or confidence. Research has documented a negative relationship between listening anxiety and listening comprehension (e.g. Elkhafaifi, 2005; Golchi, 2012; Ghapanchi \& Golparvar, 2012; Tsai, 2013; Serraj \& Noordin, 2013). Conversely, self-efficacy or confidence in listening has been found to correlate positively with listening achievement (Chen, 2007; Magogwe \& Oliver, 2007; Rahimi \& Abedini, 2009)

Possessing strong linguistic proficiency, language learners can overcome the problematic areas of listening and be effective listeners. Unfortunately, this does not apply to most FL learners. The use of listening comprehension strategies can therefore be of great help to such learners since strategies help them to compensate for limited proficiency. This explains the focus placed on strategic listening over the past decades. There seems to be a consensus that strategy use is what makes the difference between skilled and less skilled listeners (Vandergrift, 1997). Strategy use is recommended not only for bettering listening comprehension (Yang, 2002; Cross, 2009), but also, as suggested by Goh (2008), for improving learners' confidence and making them less anxious when involved in listening events.

Research into strategic listening has focused on identifying and classifying strategies used by learners, especially good ones, when involved in the listening process (e.g. Vandergrift, 1997, 2003; Goh, 2002; Liu, 2008). A second trend has investigated the frequency of listening strategies in different groups of language learners (e.g. Piamsai, 2005; Bidabadi \& Yamat, 2011; Tavakoli, Shahraki, \& Rezazadeh, 2012; Rahimia \& Katala, 2012). A third line of research has examined the relationship between strategy use and such variable as listening comprehension, anxiety, and self-efficacy (e.g. Chen, 2007; Magogwe \& Oliver, 2007; Liu, 2008; Mohseny \& Raeisi, 2009; Rahimi \& Abedini, 2009; Golchi, 2012; Serraj \& Noordin, 2013; Tsai, 2013). A fourth research trend has tested the reflection of strategy instruction on listening achievement and other factors that relate to the listening process (e.g. Carrier, 2003; Graham \& Macaro, 2008; Cross, 2009; Coşkun, 2010; Rahimi \& Katal, 2013; Bozorgian \& Pillay, 2013; Rasouli, Mollakhan, \& Karbalaei, 2013; Dousti \& Abolfathiasl, 2013; Yekta, Jahandar, \& Khodabandehlou, 2013). The area of listening strategy use still captures researchers' interest everywhere in the world. The present study was an attempt to provide a picture of listening strategy use among Egyptian EFL learners. It aimed to investigate the strategies used frequently by Egyptian EFL college sophomores. It also examined the relationship between students' strategy use and their listening comprehension and self-efficacy. The identification of frequent strategies can illuminate subsequent endeavors to provide effective strategy instruction to any given group of language learners.

\section{Statement of the Problem}

Listening comprehension is problematic for many FL learners. Researchers attribute this to factors that relate to characteristics of the listener, text, task, and process (Rubin, 1994). Goh (2000) empirically identified several barriers that hinder EFL learners' listening comprehension. These are affective barriers, habitudinal barriers, information processing barriers (e.g., processing speed, input retention, interpretation), English proficiency, strategic barriers (e.g., having problems conducting the proper strategies), belief barriers (e.g., attending to every word or demanding full comprehension of text), and material barriers (e.g., difficulty level of materials, text genre, topics). To overcome all these sources of difficulty, FL learners need to be strategic listeners. The identification of listening strategies used more often by FL learners in a given context can provide valuable information for strategy training interventions. The area of strategic listening has not so far received the due attention in the Egyptian context. Accordingly, the present study aimed to investigate the listening comprehension strategies that Egyptian EFL learners use more frequently when they listen to English material. The study also explored the relationship between EFL learners' listening strategy use, and their listening comprehension and self-efficacy. Affective variables like anxiety and self-efficacy play a significant role in listening comprehension. The use of effective listening strategies may help learners gain self-confidence in their listening ability. This is the reason for including self-efficacy as a dependent variable along with listening comprehension. More specifically, the study addressed the following questions:

1) What are the listening comprehension strategies used more often by Egyptian EFL college sophomores?

2) What is the relationship between Egyptian EFL college sophomores' listening strategy use and listening comprehension? 
3) What is the relationship between EFL Egyptian college sophomores' listening strategy use and listening self-efficacy?

4) Do students with high and low strategy frequency differ in listening comprehension?

5) Do students with high and low strategy frequency differ in listening self-efficacy?

\section{Review of Literature}

\subsection{Listening Strategy Use and Listening Proficiency}

Listening comprehension is important for language learning in general and FL learning in particular because it allows learners to internalize language items through exposure to the target language (Brown, 2001). Scholars agree that effective language learning cannot occur without receiving sufficient language input (Krashen, 1985; Peterson, 2001). Listening is a main avenue of such input. Long ago, listening was thought of as a passive skill (Jung, 2003; Vandergrift, 2004). Recently, this view has been replaced by a more accurate view that listening is an active process that entails listeners' constructing meaning by interacting with the material being listened to (Bentley \& Bacon, 1996; Nunan, 1998; Holden, 2004). This recent conception is reflected in the definition of listening offered by O'Malley, Chamot, and Kupper (1989, p. 19), "listening comprehension is an active and conscious process in which the listener constructs meaning by using cues from contextual information and from existing knowledge, while relying upon multiple strategic resources to fulfill the task requirement." With the advent of this recent view and the interest placed on learner variables, language learning strategies in general and strategy use within specific language skills in particular began to capture researchers' interest. This movement began by researchers' exploring strategies used by successful language learners on the belief that successful learners use strategies which, if identified and described, can be taught to less successful learners to better their learning. Listening research of this type has produced several, but similar taxonomies of listening strategies.

Initially, researchers based their work in listening strategies on general language learning strategy taxonomies (e.g., Oxford, 1990; O'Malley \& Chamot, 1990). The strategy model proposed by O'Malley and Chamot (1990) was used extensively. Later, strategy models were developed especially for listening. Two of such models were based on O'Malley-Chamot's model (Vandergrift, 1997, 2003; Flowerdew \& Miller, 2005). Strategies in these two models are organized under the three main types of metacognitive, cognitive and socioaffective strategies. Metacognitive strategies are management techniques employed by learners to control their learning through planning, monitoring, evaluating, and modifying (Rubin, 1987). Metacognitive strategies include planning (advance organization, selective attention, self-management), monitoring (comprehension monitoring and Double-check monitoring), and evaluating (self-assessment). Cognitive strategies are strategies listeners use to manipulate the material to be listened to by understanding the linguistic input. Cognitive strategies includes resourcing (finding and using appropriate resources), grouping, note-taking, elaboration of prior knowledge, summarizing, deduction/induction, imagery, auditory representation and making inferences. Socioaffective strategies, as defined by Vandergrift (2003), are techniques listeners employ to collaborate with others, to verify understanding, or to lower anxiety. Socioaffective strategies encompass questioning for clarification, cooperation and self-talk. In more recent work, Vandergrift, Goh, Mareschal, and Tafaghodtari (2006 developed a wider taxonomy of listening strategies that used different labels of strategy categories: problem-solving, planning and evaluation, mental translation, person knowledge, and directed attention. Problem-solving includes strategies used by listeners to inference and monitor inferences. Planning and evaluation represent the strategies listeners use to prepare themselves for listening, and to evaluate the results of their listening efforts. Mental translation represents strategies that listeners must learn to avoid if they are to become skilled listeners. These strategies represent an inefficient approach to listening comprehension. Person knowledge includes listeners' perceptions of the difficulty presented by L2/FL listening and their self-efficacy in L2/FL listening. Directed attention includes strategies that listeners use to concentrate and to stay on task.

A positive relationship between listening strategy use and listening proficiency has been supported empirically. Vandergrift (1997) explored the strategies of proficient and less proficient learners of French as L2. Twenty one learners from four ability levels participated in the study. Data collected from think-aloud sessions revealed differences in strategy use between proficient and less proficient listeners. The biggest difference was in the reported use of metacognitive strategies. Proficient listeners reported using more metacognitive strategies than less proficient listeners. Less proficient listeners used more surface-processing strategies such as translation and transfer, whereas proficient listeners used more deep-processing cognitive strategies such as comprehension monitoring. More recently and using the same technique (i.e. think-aloud), Vandergrift (2003a) replicated the 1997 study with 36 French learners. Results revealed that cognitive strategies were most frequent among participants, followed by metacognitive and socioaffective strategies respectively. The results also showed 
significant differences between proficient and less proficient listeners in the use of metacognitive strategies, as well as in individual strategies for comprehension monitoring, questioning for elaboration, and translation. Proficient listeners used metacognitive strategies more frequently than did less proficient listeners. The variations in metacognitive strategy use had a statistically significant relation across listening ability. Similarly, Liu (2008) investigated, among other things, the relationship between listening strategy use and listening ability of 101 Taiwanese university non-English major students. Subjects who were divided into three ability groups completed a strategy questionnaire adapted from Vandergrift (1997). Overall, results revealed a significant positive relationship between strategy use and listening proficiency. Proficient listeners proved to possess higher metacognitive (e.g. using more planning strategies), cognitive (e.g., using top-down processing) and socioaffective (e.g., controlling emotions) awareness. Of all strategies, managing attention, directed and selective attention, and advance organization were highly correlated with listening proficiency.

Mohseny and Raeisi (2009) explored the relationship between language proficiency of Iranian EFL learners and their listening strategy use. Statistical analysis showed a significant positive correlation between proficiency level and listening strategy use. Cognitive strategies proved to be the most frequent among participants. Bidabadi and Yamat (2011) identified the listening strategies employed by 92 Iranian EFL freshman university students and the reflection that strategies had on their listening proficiency. Learners from all ability levels employed metacognitive strategies more often, followed by cognitive and socioaffective strategies. A significant positive correlation was found between listening strategies employed by participants and their listening proficiency. Tavakoli, Shahraki, and Rezazadeh (2012) investigated the relationship between metacognitive awareness (planning and evaluation, problem Solving, directed attention, mental translation and person knowledge) of proficient $(\mathrm{N}=32)$ and less proficient $(\mathrm{N}=34)$ Iranian EFL learners and their performance on the listening section of IELTS. Data obtained from the strategy questionnaire developed by Vandergrift, Goh, Mareschal, and Tafaghodtari (2006) indicated that metacognitive awareness had a positive relationship with listening performance. Proficient listeners reported significantly higher use of problem solving and directed attention strategies than less proficient listeners. Less proficient listeners tended to use mental translation. No difference was found between proficient and less proficient listeners in planning and evaluation and person knowledge.

The aforementioned studies supported the existence of a positive relationship between listening strategy use and listening proficiency. In other studies, researchers provided strategy training to FL learners on the hope that such training would have a positive reflection on their listening proficiency (Carrier, 2003; Vandergrift, 2003; Vandergrift, \& Tafaghodtari, 2010; Cross, 2009; Chen, 2009; Coşkun, 2010; Bozorgian \& Pillay, 2013; Rahimi \& Katal, 2013; Rasouli, Mollakhan, \& Karbalae, 2013; Dousti \& Abolfathias, 2013). Because this research line is beyond the scope of the present study, just a few intervention studies would be presented as examples. Vandergrift and Tafaghodtari (2010) trained 59 students of French as a second language in the use of some metacognitive strategies, namely prediction, planning, monitoring, evaluating and problem solving. A control group of 47 students listened to the same texts without metacognitive instruction. The experimental group outperformed the control group in listening comprehension. Less proficient listeners in the experimental group made greater gains than their more proficient counterparts. Rahimi and Katal (2013) investigated the effect of metacognitive instruction on pre-university EFL learners' awareness of listening strategies, listening comprehension, and oral language proficiency. Learners who received the proposed metacognitive instruction achieved significantly higher gains in metacognitive awareness and speaking proficiency than learners who received conventional listening instruction without strategy training. A difference between the listening performance of the experimental and control groups was found in favor of the experimental group, but it did not reach the level of statistical significance. Bozorgian and Pillay (2013) delivered a 14-week listening strategy instruction to Iranian EFL lower intermediate female learners using learners first language, Persian. Instruction covered five listening strategies: guessing, making inferences, identifying topics, repetition and note-taking. Students who received the proposed instruction performed significantly better on a listening comprehension posttest than students who did the same listening activities without strategy training.

\subsection{Listening Strategy Use and Listening Anxiety/Self-Efficacy}

FL listening is highly anxiety provoking for several reasons. One important reason is that listening comprehension entails online processing (Gonen, 2009) of linguistic and background information, and coping with the uncontrollable speed of delivery. It therefore involves a great deal of mental processes (Vandergrift, 1999). This demanding nature of FL listening can be accompanied by what Joiner (1986) calls negative listening self-concept. This negative self-concept is another face of anxiety and lack of self-efficacy or confidence. In a study (Tsai 2013) probing, among other things, causes of FL listening anxiety from the perspective of FL learners, 102 Taiwanese high school students attributed their anxiety to listening time constraint, fast speaking 
speed, lack of prior knowledge, and lack of adequate knowledge about vocabulary and topics. Besides, less proficient listeners were found to have higher listening anxiety than their proficient counterparts. Research has documented a negative relationship between listening anxiety and listening comprehension. Serraj and Noordin (2013) examined the relationship between listening comprehension, foreign language anxiety and foreign language listening anxiety. Questionnaire data of 210 Iranian EFL students revealed a negative correlation between foreign language listening anxiety and listening comprehension. Elkhafaifi (2005) documented a negative correlation between general FL learning anxiety and listening comprehension of 233 postsecondary students of Arabic as a FL. Based on the findings, the researcher concluded that reducing student anxiety and providing a less stressful classroom environment might help students improve both their listening comprehension proficiency as well as their overall course performance. Golchi (2012) explored the relationship between listening anxiety, listening strategy use and listening comprehension among Iranian learners. Three instruments were administered to 63 IELTS learners from two language institutes in Shiraz: a listening anxiety questionnaire, a listening comprehension strategy questionnaire and an IELTS listening test. The results revealed that listening anxiety had negative correlation with listening comprehension and listening strategy use. Moreover, the findings showed that low anxious learners used metacognitive strategies more often than did high anxious learners.

Self-efficacy, i.e., learners' beliefs in their capability to succeed in listening tasks can be seen as an opposite of listening anxiety. Bernhardt (1997) describes self-efficacious learners as learners who: feel really confident because of the experiences they have gained in solving problems and the approaches they have developed based on those problem solving experiences. It is therefore argued that self-efficacy is a major predictor of student achievement in addition to knowledge, skill, value, and expectation (Schunk, 2003), for it determines learners' willingness to expend effort in the activity concerned (Wigfield \& Guthrie, 1997). The significance of self-efficacy is reflected in Bandura's proposition that "perceptions of self-efficacy influence motivation; they determine the goals individuals set, the effort they expend to achieve these goals, and their willingness to persist in the face of failure" (1994, p. 72). The positive reflection of self-efficacy beliefs on FL achievement was documented in a study by Chen (2007) using a sample of college Taiwanese students. A significant and positive relationship between self-efficacy beliefs and listening achievement was found. The results also showed that students' self-efficacy beliefs were much stronger predicators of language performance in the area of listening than students' anxiety and perceived value were. Similarly, Rahimi and Abedini (2009) examined the relationship between self-efficacy and listening comprehension among 61 Iranian EFL college freshmen. Data collected by an author-designed self-efficacy questionnaire and a listening test indicated that listening self-efficacy correlated significantly with listening proficiency.

The use of listening strategies can enhance students' listening self-efficacy, as they can help students overcome barriers that hinder listening comprehension and develop a more positive listening self-concept. This proposition has been supported in a number of studies conducted in FL settings. Siew and Wong (2005) investigated the relationship between language learning self-efficacy and language learning strategies among 74 graduate Malaysian English pre-service teachers. Two author-designed questionnaires were used to probe participants' self-efficacy about English language learning and language learning strategy use. A significant positive relationship was found between language learning strategies and language self-efficacy. This same finding was reached by Magogwe and Oliver (2007) in a study conducted on 480 students from primary schools, secondary schools, and a tertiary institution. Data collected by a modified version of Oxford's Strategy Inventory for Language Learning (SILL) and the Morgan-Jinks Student Efficacy Scale (MJSES) revealed a significant and positive relationship between self-efficacy and overall use of language learning strategies for students from the three proficiency levels. Graham and Macaro (2008) investigated the effects of strategy instruction on the listening performance and self-efficacy of 68 lower-intermediate learners of French in England. As expected by the researchers, strategy instruction improved participants' listening proficiency and confidence about listening.

\section{Method}

\subsection{Participants}

Eighty four male and female sophomore English majors at Tanta Faculty of Education participated in the study. Students majoring in English at Egyptian faculties of education are prepared to be teachers of English at the pre-university stage. The mean age of the participants was 20 years. Their average experience in studying English was seven years.

\subsection{Instruments}

Three instruments were used for data collection in the present study: a Listening Comprehension Test, a Listening Strategy Questionnaire and a Listening Self-efficacy Questionnaire. The Listening Comprehension 
Test was adapted from paper-based Longman TOEFL test (Phillips, 2001). It consisted of two parts with 40 multiple choice items. In part A, students heard 30 short conversations and answered a question after each conversation. In part B, they heard three long conversations and answered 10 questions on them. Conversations that are culturally-laden were avoided so that cultural knowledge would not interfere with results (See appendix $\mathrm{C}$ for sample conversations and questions). The Listening Strategy Questionnaire (See appendix A) was constructed based on a survey of relevant widely used questionnaires (Vandergrift \& Tafaghodtari, 2010; Vandergrift, Goh, Mareschal, \& Tafaghodtari, 2006; Harris, 2007; Cheng, 2002; Lee, 1997; Teng, 1996). It consisted of 39 items probing students' use of three types of listening comprehension strategies: metcognitive (N $=18)$, cognitive $(\mathrm{N}=18)$ and socioaffective $(\mathrm{N}=3)$. Participants were asked to rate each strategy statement on a 5-point rating scale ranging from 5 "Always" to 1 "Never". Two items were reverse coded so that higher scores indicated higher strategic awareness: the item about translating into the mother tongue (item 2) and the item about stopping listening when having comprehension difficulties (item 19).

The Listening Self-efficacy Questionnaire (See appendix B) consisted of 40 items. Relevant literature on self-efficacy and anxiety questionnaires (Hortwiz, 1986; Henk \& Melnick, 1995; Nezami, Schwarzer, \& Jerusalem, 1996; Jinks \& Morgan, 1999; Seeger, 2009; Rahimi \& Abedini, 2009) helped the researcher in developing the items of the questionnaire used in the present study. It is noteworthy that the researcher followed the framework of the Reader Self-Perception Scale (RSPS) developed by Henk and Melnick (1995) in constructing the present study's self-efficacy questionnaire. The RSPS is a reading scale, yet the researcher used it as the main reference since the self-efficacy construct in reading and listening is similar to a large extent. More specifically, the researcher adapted and developed items under three of the RSPS's dimensions: (1) progress: how one's perception of present performance compares with past performance, (2) observational comparison: how a student perceives his or her performance compared with the performance of classmates, and (3) physiological states: internal feelings that one experiences during listening (Henk \& Melnick, 1995, p. 472). Two other dimensions were added by the researcher: (1) strategic awareness: knowing how to handle the listening task and overcome difficulties, and (2) challenge: willingness to do challenging listening tasks. Participants were asked to respond to items by indicating how far they agree to the statements on a 5-point rating scale. Each response was associated with a point value, where "Strongly agree" was assigned a point value of 5 and the response "Strongly disagree" a point value of 1 . Items with negative statement were reverse coded so that higher scores indicated higher self-efficacy.

The three instruments were content validated by three EFL professors to decide on their face validity and appropriateness for the target population. They were then pilot tested on 30 students (rather than those who participated in the main experiment) to check their internal consistency. The alpha estimates for the internal consistency of the Listening Comprehension Test, the Listening Strategy Questionnaire and the Listening Self-efficacy Questionnaire were .76, $.94, .92$ respectively.

\subsection{Data Collection Procedure}

The instruments were administered to participants in two sessions so that fatigue and boredom would not affect results. The Listening Strategy and the Listening Self-efficacy Questionnaires were given to the participants in one session in a regular classroom, and the Listening Comprehension Test was administered in another session in the Language Lab. Participants were told that their scores on the three instruments would be used only for research purposes.

\subsection{Data Analysis}

The data obtained from the instruments were coded for statistical treatment. The Statistical Package for the Social Sciences (SPSS, version 15) was used for statistical analysis. Descriptive statistics were applied to obtain patterns of strategy use. Pearson correlations were computed to explore the relationship between strategy use and listening comprehension and self-efficacy. To make sure that Pearson correlation statistics was appropriate for the current data, One-Sample Kolmogorov-Smirnov test was used to determine whether scores followed a normal distribution. The results showed that the $p$-values of the variables were not significant $(p=.235, .647$ and .172 for the Strategy Questionnaire, the Self-efficacy Questionnaire and the Listening Comprehension Test respectively), i.e., the data followed a normal distribution. Independent samples t-test was also conducted to determine if there were significant differences in listening comprehension and self-efficacy by strategy use.

\section{Results}

\subsection{Pattern of Listening Strategy Use}

Means and standard deviations were computed to investigate students' pattern of listening strategy use. In 
calculating the frequency of strategies, the researcher followed Oxford's (2001) scoring system: high (mean of 3.5 or higher), medium (mean of 2.5-3.4), and low (mean of 2.4 or lower). Descriptive statistics in table 1 below showed that the mean of overall listening strategy use is $3.217(\mathrm{SD}=.43)$, which indicates an overall medium strategy use. As to strategy categories, participants used cognitive strategies more often $(\mathrm{M}=3.479 ; \mathrm{SD}=.32)$. Using Oxford's scoring system, participants' use of cognitive strategies is high. The second frequently used category of listening strategies is metacognitive strategies $(\mathrm{M}=3.360$; $\mathrm{SD}=.49)$, followed by socioaffective strategies $(\mathrm{M}=2.780 ; \mathrm{SD}=.55)$. Thus, the frequency of both metacognitive and socioaffective strategies among participants is medium.

Table 1. Descriptive statistics of listening strategy use

\begin{tabular}{llll}
\hline & $\mathrm{N}$ & $\mathrm{M}$ & $\mathrm{SD}$ \\
\hline Cognitive strategies & 84 & 3.479 & .32 \\
Metacognitive strategies & 84 & 3.360 & .49 \\
Socioaffective strategies & 84 & 2.780 & .55 \\
Overall strategy use & 84 & 3.217 & .43 \\
\hline
\end{tabular}

\subsection{The Relationship between Strategy Use and Listening Comprehension}

Pearson correlation coefficients were computed to explore the relationship between students' listening strategy use and listening comprehension. The strength of correlation was interpreted according to Cohen's rule (1988): $\mathrm{r}$ $=0.10$ to 0.29 shows small correlation; $r=0.30$ to 0.49 indicates medium correlation; and $r=0.50$ to 1.0 reveals large correlation. As listed in table 2, the results indicated a strong positive correlation between overall listening strategy use and listening comprehension $(\mathrm{r}=.62)$. As to strategy categories, strong positive correlations were found between listening comprehension on one hand and metacognitive $(r=.62)$ and cognitive $(r=.60)$ strategies on the other hand. Socioaffective strategies correlated moderately $(r=.25)$ with listening comprehension.

Table 2. Correlations between listening strategy use and listening comprehension

\begin{tabular}{lll}
\hline & \multicolumn{2}{l}{ Listening Comprehension } \\
\hline Cognitive & Pearson Correlation & $.60\left(^{* *}\right)$ \\
strategies & Sig. (2-tailed) & .000 \\
& $\mathrm{~N}$ & 84 \\
Metacognitive & Pearson Correlation & $.62\left(^{* *}\right)$ \\
strategies & Sig. (2-tailed) & .000 \\
& $\mathrm{~N}$ & 84 \\
Socioaffective & Pearson Correlation & $.25(*)$ \\
strategies & Sig. (2-tailed) & .022 \\
& $\mathrm{~N}$ & 84 \\
Total & Pearson Correlation & $.62(* *)$ \\
& Sig. (2-tailed) & .000 \\
& $\mathrm{~N}$ & 84 \\
\hline
\end{tabular}

$* * \mathrm{p}<0.1 * \mathrm{p}<.05$.

\subsection{The Relationship between Strategy Use and Listening Self-Efficacy}

Pearson correlation coefficients in table 3 below pertain to the relationship between students' listening strategy use and listening self-efficacy. A strong positive correlation was found between self-efficacy about listening on one hand and cognitive strategies $(r=60)$, metacognitive strategies $(r=.58)$ and overall strategy use $(r=.60)$ on 
the other hand. The relationship between socioaffective strategies and self-efficacy proved to be moderate ( $\mathrm{r}$ $=.24)$.

Table 3. Correlations between listening strategy use and listening self-efficacy

\begin{tabular}{|c|c|c|}
\hline \multicolumn{3}{|c|}{ Listening Comprehension } \\
\hline \multirow{3}{*}{$\begin{array}{l}\text { Cognitive } \\
\text { strategies }\end{array}$} & Pearson Correlation & $.60(* *)$ \\
\hline & Sig. (2-tailed) & .000 \\
\hline & $\mathrm{N}$ & 84 \\
\hline \multirow{3}{*}{$\begin{array}{l}\text { Metacognitive } \\
\text { strategies }\end{array}$} & Pearson Correlation & $.58(* *)$ \\
\hline & Sig. (2-tailed) & .000 \\
\hline & $\mathrm{N}$ & 84 \\
\hline \multirow{3}{*}{$\begin{array}{l}\text { Socioaffective } \\
\text { strategies }\end{array}$} & Pearson Correlation & $.24(*)$ \\
\hline & Sig. (2-tailed) & .028 \\
\hline & $\mathrm{N}$ & 84 \\
\hline \multirow[t]{3}{*}{ Total } & Pearson Correlation & $.60(* *)$ \\
\hline & Sig. (2-tailed) & .000 \\
\hline & $\mathrm{N}$ & 84 \\
\hline
\end{tabular}

\subsection{Differences in Listening Comprehension by Listening Strategy Use}

An independent samples t-test was conducted to assess differences in listening comprehension by listening strategy use. For this purpose the participants were divided into two groups: high and low strategy users (participants whose strategy frequency exceeded the average were considered high strategy users and those whose strategy frequency was under the average were low strategy users). This was done with overall strategy use and individual strategy categories. Significant differences were found in listening comprehension between high users of metacognitive $(\mathrm{M}=32.12 ; \mathrm{SD}=3.67)$ and cognitive $(\mathrm{M}=32.73 ; \mathrm{SD}=3.24)$ strategies, and low users of metacognitive $(\mathrm{M}=27.97 ; 3.32)$ and cognitive $(\mathrm{M}=27.58 ; \mathrm{SD}=3.27)$ strategies in favor of high strategy users $(t=5.42,6.80$ and 2.33 respectively; $p<.05)$. No difference in listening comprehension was found between high and low users of socioaffective strategies $(t=1.80 ; \mathrm{p}>.05)$. The difference in listening comprehension by overall strategy use was significant. High strategy users $(\mathrm{M}=32.53 ; \mathrm{SD}=3.39)$ outperformed their low counterparts $(\mathrm{M}=27.80 ; \mathrm{SD}=3.23)$ in listening comprehension $(\mathrm{t}=6.55 ; \mathrm{p}<.05)$. These statistics are presented in the following table:

Table 4. Means, standard deviations and t-values for the mean differences between high and low strategy users on listening comprehension

\begin{tabular}{lllllll}
\hline & Group & $\mathrm{N}$ & $\mathrm{M}$ & $\mathrm{SD}$ & t-value & Sig. \\
\hline Metacognitive & HSU & 41 & 32.12 & 3.67 & \multirow{2}{*}{5.42} & .000 \\
strategies & LSU & 43 & 27.97 & 3.32 & & \\
Cognitive & HSU & 37 & 32.73 & 3.24 & & \\
strategies & LSU & 47 & 27.85 & 3.27 & & .000 \\
Socioaffective & HSU & 39 & 30.84 & 4.38 & & \\
strategies & LSU & 45 & 29.26 & 3.64 & 1.80 & .075 \\
Overall & HSU & 39 & 32.53 & 3.39 & & \\
strategies & LSU & 45 & 27.80 & 3.23 & & .000 \\
\hline
\end{tabular}

Note. HSU $=$ High Strategy Users \& LSU = Low Strategy Users 


\subsection{Differences in Listening Self-Efficacy by Listening Strategy Use}

The independent samples t-test statistics in the following table shed light on the differences in self-efficacy about listening by listening strategy use. Data reveal a significant difference in self-efficacy by overall strategy use. High strategy users $(M=137.17 ; \mathrm{SD}=14.90)$ outperformed their low counterparts $(\mathrm{M}=120.24 ; \mathrm{SD}=11.25)$ in self-efficacy about listening $(\mathrm{t}=6.55 ; \mathrm{p}<.05)$. As to individual strategy categories, significant differences were detected in self-efficacy between high users of metacognitive $(M=135.70 ; S D=16.25)$ and cognitive $(M=$ 137.69; $\mathrm{SD}=14.94)$ strategies and low users of metacognitive $(\mathrm{M}=121.34 ; \mathrm{SD}=11.44)$ and cognitive $(\mathrm{M}=$ 120.26; $\mathrm{SD}=11.24)$ strategies in favor of high users $(\mathrm{t}=4.69$ and 6.08 respectively; $\mathrm{p}<.05)$. No difference was found in self-efficacy between high and low socioaffective strategy users $(t=1.07 ; p>.05)$.

Table 5. Means, standard deviations and t-values for the mean differences between high and low strategy users on listening self-efficacy

\begin{tabular}{lllllll}
\hline & Group & N & M & SD & t-value & Sig. \\
\hline Metacognitive & HSU & 41 & 135.70 & 16.25 & \multirow{2}{*}{4.69} & .000 \\
strategies & LSU & 43 & 121.34 & 11.44 & & \\
Cognitive & HSU & 37 & 137.69 & 14.94 & \multirow{2}{*}{6.08} & .000 \\
strategies & LSU & 47 & 120.26 & 11.24 & & \\
Socioaffective & HSU & 39 & 130.36 & 17.70 & & \\
strategies & LSU & 45 & 126.69 & 14.30 & 1.07 & .288 \\
Overall & HSU & 39 & 137.17 & 14.90 & & \\
strategies & LSU & 45 & 120.24 & 11.25 & 6.10 & .000 \\
\hline
\end{tabular}

\section{Discussion}

The study explored the pattern of listening strategy use among a group of Egyptian EFL college sophomores. Descriptive statistics of the Listening Strategy Questionnaire revealed that participants used cognitive strategies more often, followed by metacognitive and socioaffective strategies. This same pattern was reported by Mohseny and Raeisi (2009) who experimented with a comparable sample of Iranian EFL learners. Vandergrift (2003) also reported this pattern with 36 French learners. Some other studies reported metacognitive strategies as the most frequent among EFL learners, followed by cognitive and socioaffective strategies (Bidabadi \& Yamat, 2011). This means that cognitive and metacognitive strategies alternate being the most preferred among EFL learners. Socioaffective strategies always come last. A possible explanation for the high frequency of cognitive strategies in the present study is popularity of inferencing and use of background knowledge. Strategies that incorporate inferencing and use of background knowledge received highest mean values (See appendix A for the mean values of all the 39 strategies presented in a descending order). This seems logical since inferencing and use of background knowledge help FL learners overcome limited language proficiency and cope with the complexities of the listening task. The somehow infrequent use of socioaffective strategies can be due to a tendency to individuality in some EFL settings, like the Egyptian one. Noticeable infrequent use of socioaffective strategies led researchers to omit them from analysis in a study that explored the relationship between listening strategies and learner factors like motivation (Serri, Boroujeni, \& Hesabi, 2012). Another possible explanation is that socioaffective strategies need to be taught to EFL students. For instance, EFL students may need to be taught how to relax so as not to lose concentration while listening. Riazi (2007), based on similar findings, emphasized the important role of the instructor in encouraging the use of social and affective strategies compared to the other types of strategies.

The study also investigated the relationship between listening strategy use and both listening comprehension and self-efficacy about listening. Listening comprehension correlated positively with overall strategy use and the three individual strategy categories. These findings are in line with previous studies (e.g. Mohseny \& Raeisi, 2009; Bidabadi \& Yamat, 2011). Similarly, self-efficacy correlated positively with overall strategy use and the three individual strategy categories. This concurs with the findings of the studies conducted by Magogwe and Oliver (2007), Graham and Macaro (2008), and Siew and Wong (2005). Magogwe and Oliver (2007), and Siew and Wong (2005) found a significant positive relationship between overall use of language learning strategies and language self-efficacy beliefs for EFL students with different proficiency levels. Strategy instruction, in the 
study conducted by Graham and Macaro (2008), was reported to have positive reflection on learners' confidence about listening. Similarly, several studies reported negative correlation between listening strategy use and listening anxiety (e.g. Maeng, 2007; Gonen, 2009; Sioson, 2011; Lu \& Liu, 2011; Golchi, 2012). A possible explanation for this finding is that having a good repertoire of listening strategies gives students a sense of confidence and enables them to cope with the demanding nature of the listening task. Finally, concurring with other studies, high users of overall, cognitive and metacognitive strategies in the present study outperformed low users in listening comprehension (e.g. Goh, 2002; Vandergrift, 2003; Mohseny \& Raeisi, 2009; Bidabadi \& Yamat, 2011; Afshar \& Hamzavi, 2014) and self-efficacy about listening (e.g. Siew \& Wong, 2005; Magogwe \& Oliver, 2007; Graham \& Macaro, 2008). No differences were found in listening comprehension or self-efficacy of high and low users of socioaffective strategies, which is an issue that needs to be researched.

\section{Implications}

The present study revealed that frequent listening strategy use is good for FL learners' listening comprehension and self-efficacy about listening. The importance of possessing enhanced listening comprehension and higher self-efficacy about listening in the population of the present study is twofold. It helps them with their academic study and furnishes them with skills and attitudes that they need to impart to their students when they are full teachers. These results therefore provide a rationale for teaching listening strategies in the FL classroom. What makes the teaching of such strategies to FL learners of great significance is the demanding nature of the listening task. Listening comprehension, as confirmed by Gonen (2009), entails online processing of linguistic and background information, and coping with the uncontrollable speed of delivery. For this reason, listening involves a great deal of mental processes (Vandergrift, 1999). Thus, direct teaching of listening strategies to FL learners, especially those with poor listening proficiency and/or high levels of anxiety associating listening is recommended not only for bettering listening comprehension, but also, as suggested by Goh (2008), for improving learners' confidence and making them less anxious when involved in listening events. A topic that needs to be further researched as revealed in the present study and several other studies is FL learners' infrequent use of socioaffective strategies. Research in this area needs to investigate the reasons for infrequent use and the effect on teaching socioaffective strategies on listening proficiency.

The small sample in the present study makes it difficult to generalize the findings of this research to the entire population of EFL learners in Egypt. Future research needs to be conducted on a wider scale in order to generalize the findings to the entire population. However, the study outlined the pattern of listening strategy use among 84 English majors at Tanta Faculty of Education. This pattern can be made use of in any future endeavors to update curricula in English departments at faculties of education.

\section{References}

Bandura, A. (1994). Encyclopedia of human behavior (Vol. 4). Academic Press.

Bentley, S., \& Bacon, S. (1996). The all new, state-of-the-art ILA definition of listening: Now that we have it, what do we do with it? Listening Post, 56, 1-5.

Bernhardt, S. (1997). Self-efficacy and second language learning. The NCLRC Language Resource, 1(5).

Bidabadi, F., \& Yamat, H. (2011). The relationship between listening strategies used by Iranian EFL freshman university students and their listening proficiency levels. English Language Teaching, 4(1), 26-32.

Bozorgian, H., \& Pillay, H. (2013). Enhancing Foreign Language Learning through Listening Strategies Delivered in L1: An Experimental Study. International Journal of Instruction, 6(1), 105-122.

Brown, H. (2001). Teaching by principles: An interactive approach to language pedagogy (2nd ed.). New York: Longman.

Carrier, K. (2003). Improving High School English language learners' second language listening through strategy instruction. Bilingual Research Journal, 27, 383-408.

Chen, A. (2009). Listening Strategy Instruction: Exploring Taiwanese College Students' Strategy Development. The Asian EFL Journal Quarterly, 11(2), 54-85.

Chen, H. (2007). The Relationship between EFL Learners' Self-Efficacy Beliefs and English Performance. Retrieved from http://diginole.lib.fsu.edu/etd/3846/

Cheng, C. (2002). Effects of Listening Strategy Instruction on Junior High School Students (pp. 289-297). The Eleventh International Symposium on English Teaching/Fourth Pan Asian Conference. Taiwan, Crane.

Cohen, J. (1988). Statistical power analysis for the behavioral sciences. Hillsdale, NJ: Erlbaum. 
Coşkun, A. (2010). The effect of metacognitive strategy training on the listening performance of beginner students. Novitas-ROYAL, 4(1), 35-50.

Cross, J. (2009). Effects of listening strategy instruction on news videotext comprehension. Language Teaching Research, 13, 151-176.

Dousti, H., \& Abolfathias, H. (2013). The Effect of Metacognitive Listening Strategy Training on EFL Learners' Listening Sub-skills Performance. International Journal of Applied Linguistics \& English Literature, 2(4), $50-55$.

Elkhafaifi, H. (2005). Listening Comprehension and Anxiety in the Arabic Language Classroom. The Modern Language Journal, 89 (ii), 206-220.

Ferris, D. (1998). Students' Views of Academic Aural/Oral Skills: A Comparative Needs Analysis. TESOL Quarterly, 32(2), 289-318.

Flowerdew, J., \& Miller, L. (2005). Second language listening: Theory and practice. New York: Cambridge University Press.

Ghapanchi, Z., \& Golparvar, S. (2012). Foreign language listening anxiety in Iranian EFL context. International Journal of Social Sciences and Humanities, 1, 16-22.

Goh, C. (2000). A cognitive perspective on language learners' listening comprehension problems. System, 28(1), 55-57.

Goh, C. (2002). Teaching listening in the language classroom. SEAMEO Regional Language Centre, Singapore.

Goh, C. (2008). Metacognitive instruction for second language listening development: Theory, practice and research implications. RELC Journal, 39, 188-213.

Golchi, M. (2012). Listening anxiety and its relationship with listening strategy use and listening comprehension among Iranian IELTS learners. International Journal of English Linguistics, 2(4), 115-128.

Gonen, M. (2009). The relationship between FL listening anxiety and foreign language listening strategies: The case of Turkish EFL learners. Proceedings of the 5th WSEAS/IASME International Conference on Educational Technologies (EDUTE' 09).

Graham, S., \& Macaro, E. (2008). Strategy instruction in listening for lower intermediate learners of French. Language Learning, 58, 747-778.

Griffiths, R. (1992). Speech rate and listening comprehension: Further evidence of the relationship. TESOL Quarterly, 26(2), 385-390.

Harris, V. (2007). Exploring progression: reading and listening strategy instruction with near-beginner learners of French. Language Learning, 35(2), 189-204.

Henk, W., \& Melnick, S. (1995). The Reader Self-Perception Scale (RSPS): A new tool for measuring how children feel about themselves as readers. The Reading Teacher, 48, 470-482.

Higgins, J. (1997). Students' listening difficulties: The contribution of speech rate. In C. Zaher (Ed.), Proceedings of the third EFL Skills Conference: New Directions in Listening. The Center for Adult and Continuing Education, the American University in Cairo.

Holden, W. (2004). Facilitating Listening Comprehension: Acquiring Successful Strategies. Bulletin of Hokuriku University, 28, 257-266.

Horwitz, E. (1986). Preliminary evidence for the reliability and validity of a foreign language anxiety scale. TESOL Quarterly, 20, 559-562.

Jinks, J., \& Morgan, V. (1999). Children's perceived academic self-efficacy: An inventory scale. The Clearing House, 72(4), 224-230.

Joiner, E. (1986). Listening in the Foreign Language. In B. H. Wing (Ed.), Listening, Reading, and Writing: Analysis and Application (pp. 43-70). Middlebury, VT: Northeast Conference on the Teaching of Foreign Languages.

Jung, E. (2003). The role of discourse signaling cues in second language listening comprehension. The Modern Language Journal, 87, 562-577.

Krashen, S. (1985). The input hypotheses: Issues and implications. Harlow: Longman. 
Lee, H. M. (1997). A study of the listening comprehension strategies of junior college EFL listening in Taiwan. Proceedings of the Fourteenth International Symposium on English Teaching. Taipei, Taiwan, R.O.C.: The Crane Publishing Co., Ltd.

Liu, H. (2008). A study of the interrelationship between listening strategy use, listening proficiency levels, and learning style. ARECLS, 5, 84-104.

Long, D. (1990). What you don't know can't help you: An exploratory study of background knowledge and second language listening comprehension. Studies in Second Language Acquisition, 12, 65-80.

Lu, Z., \& Liu, M. (2011). Foreign language anxiety and strategy use: A study with Chinese undergraduate EFL learners. Journal of Language Teaching and Research, 2, 1298-1305.

Maeng, U. (2007). Learning Anxiety, Listening Strategies and the Proficiency of Elementary School Learners. English Language and Linguistics, 24, 259-284.

Magogwe, J., \& Oliver, R. (2007). The relationship between language learning strategies, proficiency, age and self-efficacy beliefs: A study of language learners in Botswana. System, 35, 338-352.

Mohseny, A., \& Raeisi, N. (2009). The Relationship between Language Proficiency of EFL Students and Their Strategy Use in Listening Comprehension. TEFLL, 1(4), 111-132.

Morley, J. (1999). Current perspectives on improving aural comprehension. ESL Magazine, 2(1), 16-19.

Nezami, E., Schwarzer, R., \& Jerusalem, M. (1996). Persian adaptation (Farsi) of the general self-efficacy scale. Retrieved from http://userpage.fu-berlin.de/ health/engscal.htm

Nunan, D. (1998). Approaches to Teaching Listening in the Language Classroom. Paper presented at the Korea TESOL Conference, Seoul.

O’Malley, J., \& Chamot, A. (1990). Learning strategies in second language acquisition. Cambridge: Cambridge University Press.

O’Malley, J., Chamot, A., \& Kupper, L. (1989). Listening comprehension strategies in second language acquisition. Applied Linguistics, 10, 418-437.

Oxford, R. (1990). Language learning strategies: What every teacher should know. Boston, MA: Heinle \& Heinle.

Oxford, R. (2001). Language learning strategies. In R. Carter, \& D. Nunan (Eds.), Teaching English to speakers of other languages (pp. 166-172). Cambridge: Cambridge University Press.

Peterson, P. (2001). Skills and strategies for proficient listening. In M. Celce-Murcia (Ed.), Teaching English as a second or foreign language. Boston: Heinle \& Heinle.

Phillips, D. (2001). Longman complete course for the TOFEL test. Longman: New York.

Piamsai, C. (2005). Learner Strategies and Student Performance on a Computer-based Listening Test. The 13th Annual KOTESOL International Conference: From concept to context: Trends and challenges.

Purdy, M. (1997). What is listening? In M. Purdy, \& D. Borisoff (Eds.), Listening in everyday life: A personal and professional approach (2nd ed., pp. 1-20). Lanham, MD: University Press of America.

Rahimi, A., \& Abedini, A. (2009). The interface between EFL learners' self-efficacy concerning listening comprehension and listening proficiency. Novitas-ROYAL, 3(1), 14-28.

Rahimi, M., \& Katal, M. (2013). The Impact of Metacognitive Instruction on EFL Learners' Listening Comprehension and Oral Language Proficiency. The Journal of Teaching Language Skills (JTLS), 5(2), 69-90.

Rasouli, M., Mollakhan, K., \& Karbalaei, A. (2013). The effect of metacognitive listening strategy training on listening comprehension in Iranian EFL context. European Online Journal of Natural and Social Sciences, 2(1), 115-128.

Riazi, A. (2007). Language learning strategy use: Perceptions of female Arab English majors. Foreign Language Annals, 40(3), 433-440.

Rost, M. (2002). Teaching and Researching Listening. London, UK: Longman.

Rubin, J. (1987). Learner strategies: Theoretical assumptions, research history and typology. In L. Wenden, \& J. Rubin (Eds.), Learner strategies in language learning (pp. 15-30). Englewood Cliffs, NJ: Prentice-Hal. 
Rubin, J. (1994). A review of second language listening comprehension research. The Modern Language Journal, 78(2), 199-217.

Schunk, D. (2003). Self-Efficacy for Reading and Writing: Influence of Modeling, Goal Setting, and Self-Evaluation. Reading and Writing Quarterly, 19, 159-172.

Seeger, V. (2009). Collaborative retrospective miscue analysis: A pathway to self-efficacy in reading (Unpublished Thesis). Retrieved from http://krex.k-state.edu/dspace/handle/2097/2163

Serraj, S., \& Noordin, N. (2013). Relationship among Iranian EFL Students' Foreign Language Anxiety, Foreign Language Listening Anxiety and Their Listening Comprehension. English Language Teaching, 6(5), 1-12.

Serri, F., Boroujeni, A., \& Hesabi, A. (2012). Cognitive, Metacognitive, and Social/Affective Strategies in Listening Comprehension and Their Relationships with Individual Differences. Theory and Practice in Language Studies, 2(4), 843-849.

Siew, L., \& Wong, M. (2005). Language learning strategies and language self-efficacy: Investigating the relationship in Malaysia. Eric Journal, 36(3), 245-269.

Sioson, C. (2011). Language learning strategies, beliefs, and anxiety in academic speaking task. Philippine ESL Journal, 7, 3-27.

Tavakoli, M., Shahraki, S., \& Rezazadeh, M. (2012). The relationship between metacognitive awareness and EFL listening performance: focusing on IELTS higher and lower scorers. The Journal of Language Teaching and Learning, 2, 24-37.

Teng, H. (1997). An investigation of EFL listening strategies by Taiwanese college students. Proceedings of the Sixth International Symposium on English Teaching (Vol. 6, pp. 509-520). Taipei, Taiwan: The Crane Publishing Co., Ltd.

Tsai, C. (2001). An investigation into English as a foreign language listening anxiety among Taiwanese senior high school students. International Journal of Learning \& Development, 3(4), 108-113.

Underwood, M. (1989). Teaching listening. New York: Longman.

Vandergrift, L., \& Tafaghodtari, M. (2010). Teaching L2 Learners How to Listen Does Make a Difference: An Empirical Study. Language Learning, 60, 470-467.

Vandergrift, L. (1999). Facilitating second language listening comprehension: Acquiring successful strategies. ELT Journal, 53(3), 168-176.

Vandergrift, L. (2003). Orchestrating strategy use: Towards a model of the skilled L2 listener. Language Learning, 53, 461-494.

Vandergrift, L. (2004). Listening to learn or learning to listen? Annual Review of Applied linguistics, 24, 3-25.

Vandergrift, L. (1997). The strategies of second language (French) listeners: A descriptive study. Foreign Language Annals, 30, 387-409.

Vandergrift, L., Goh, C., Mareschal, C., \& Tafaghodtari, M. (2006). The Metacognitive Awareness Listening Questionnaire: Development and validation. Language Learning, 56, 431-462.

Vogely, A. (1999). Addressing Listening Comprehension Anxiety. In D. J. Young (Ed.), Affect in Foreign Language and Second Language Learning: A Practical Guide to Creating a Low-Anxiety Classroom Atmosphere (pp. 106-123).

Vogely, A. J. (1998). Listening comprehension anxiety: Students' reported sources and solutions. Foreign Language Annals, 31, 67-80.

Wigfield, A., \& Guthrie, J. (1997). Relations of children's motivation for reading to the amount and breadth of their reading. Journal of Educational Psychology, 89(3), 420-432.

Yang, S. L. (2002). Strategies for listening comprehension. The Proceedings of the 4th Conference on Applied English Personnel Cultivation (pp. 129-139). Nanya Institute of Technology.

Zhao, Y. (1997). The effects of listeners' control of speech rate on second language comprehension. Applied Linguistics, 18, 49-68. 


\section{Appendix A}

The listening strategy questionnaire

\begin{tabular}{llcc}
\hline St. type & Statement & M & SD \\
\hline COG & 35. I use linguistic clues to comprehend the scripts, such as prefixes and suffixes. & 3.72 & .733 \\
MET & 4. I focus harder on the text when I have trouble understanding. & 3.65 & .783 \\
COG & 10. I use my experience and knowledge to help me understand. & 3.63 & .756 \\
MET & $\begin{array}{l}\text { 27. Before listening, I concentrate my mind on the listening task and keep away } \\
\text { things that distract my attention. }\end{array}$ & 3.63 & .707
\end{tabular}

COG 5. I use the words I understand to guess the meaning of the words I don't $3.63 \quad .724$ understand.

COG 20. I use the main idea of the text to help me guess the meaning of the words that I 3.59 don't understand.

MET 9. When there's something I don't understand, I pursue trying to compensate for it. $\quad 3.58 \quad .853$

$\begin{array}{lll}\text { MET 28. I listen to what is said without paying much attention to every new word. } & 3.54 \quad .718\end{array}$

$\begin{array}{llll}\text { MET 21. I skip over words that I do not understand so that I don't miss what is said next. } & 3.54 & .841\end{array}$

\begin{tabular}{lll} 
MET & 13. I try to get back on track when I lose concentration. & 3.51 \\
\hline
\end{tabular}

COG 29. As I listen, I try to predict incoming content using the information being $3.48 \quad .843$ delivered.

MET 6. When my mind wanders, I recover my concentration right away.

COG 7. As I listen, I compare what I understand with what I know about the topic. $\quad 3.44 \quad .733$

COG 22. As I listen, I try to think in English without having to translate into my own $3.41 \quad .946$ language

COG 14. Before listening, I try to predict the words I am likely to hear based on the title. $\quad 3.41 \quad .907$

$\begin{array}{lll}\text { MET } & \text { 16. I identify my problems in listening and work on solving them. } & 3.40 \\ .746\end{array}$

MET 39. I watch TV shows or movies or listen to the radio in English to enhance my $3.39 \quad .760$ listening ability.

COG 26. I use pronunciation aspects like stress and intonation to enhance my $3.38 \quad .834$ understanding.

COG 3. Before listening, I make predictions about the listening material based on the title. $\quad 3.36 \quad .788$

$\begin{array}{lll}\text { SOA } 34 . \text { I try to relax whenever I feel tense as I listen. } & 3.35 & .551\end{array}$

MET 17. After listening, I think back to how I listened, and about what I might do $3.35 \quad .913$ differently next time.

COG 36. I use the setting and the relationship between speakers to guess the meaning $3.32 \quad 1.00$ of unknown words.

MET 37. After listening, I reflect on my problems or difficulties and how to overcome $\quad 3.27 \quad .948$ them.

MET 33. After listening, I evaluate how much I could understand.

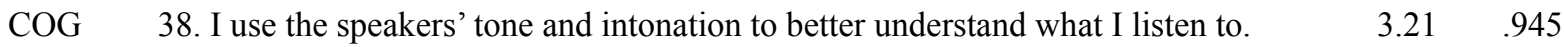

COG 15. As I listen, I quickly adjust my interpretation if I realize that it is not correct. $\quad 3.21 \quad .945$

$\begin{array}{ll}\text { MET 25. After listening, I reflect on the listening task with my classmates. } & 3.10 \quad 1.00\end{array}$

SOA 32. I talk to my teacher and classmates about how to be a better listener of English. $\quad 3.01 \quad .630$

$\begin{array}{lll}\text { COG 12. I use my knowledge of the text organization to understand the text. } & 3.01 & 1.35\end{array}$

COG 31. I picture the setting of the conversation to understand what the speakers are $3.00 \quad 1.06$ talking about.

COG 23. When I guess the meaning of a word, I think back to everything else that I have $\quad 2.76 \quad .939$ 
heard, to see if my guess makes sense.

COG 2. I translate in my head as I listen.

$2.71 \quad .951$

COG 18. After listening, I make a mental summary of what I have listened to.

$2.70 \quad 1.02$

$\begin{array}{llll}\text { MET } & \text { 1. Before I start to listen, I have a plan in my head for how I am going to listen. } & 2.53 & .783\end{array}$

$\begin{array}{llll}\text { MET 30. As I listen, I repeat important words mentally. } & 2.51 & .911\end{array}$

MET 24. As I listen, I periodically ask myself if I am satisfied with my level of $2.46 \quad 924$ comprehension.

$\begin{array}{llll}\text { MET 19. When I have difficulty understanding what I hear, I give up and stop listening. } & 2.35 & .770\end{array}$

$\begin{array}{llll}\text { SOA } & \text { 8. As I listen, I encourage myself through positive self-talk. } & 2.27 & .811\end{array}$

$\begin{array}{llll}\text { MET 11. Before listening, I think of similar texts that I may have listened to. } & 2.26 & .778\end{array}$

$\mathrm{COG}=$ Cognitive, $\mathrm{MET}=$ Metacognitive, $\mathrm{SOA}=$ Socioaffective

\section{Appendix B}

The self-efficacy questionnaire

1 Listening to English is a pleasant activity for me.

2 When I compare myself to other students in my class, I'm a good listener.

3 Before I listen to an English text, I don't feel that I'll understand it well.

4 I often end up translating word by word without understanding what I've listened to.

5 I can handle more challenging listening materials than I could before.

6 I believe that I'm a poor listener.

7 Listening material for EFL learners should be delivered at a slower rate than the rate of native speakers.

8 When listening to English, it's easy for me to make guesses about the parts I miss.

9 I feel stressed when I listen to English material.

10 I believe that my listening comprehension improves with time.

11 When I listen, I don't have to try as hard to understand as I used to do.

12 When I listen, I can answer more questions than other students.

13 I have the ability to improve my listening skill.

14 It bothers me if the teacher gives me listening assignments.

15 I understand what I listen to better than I could before.

16 I feel more relaxed and confident when I read than when I listen.

17 When listening to English material, I know how to guess difficult vocabulary items.

18 In the listening class, I like to volunteer to answer questions.

19 I often get so confused that I cannot remember what I've heard.

20 I can make a plan about the listening task before I begin to listen.

21 When I find listening difficult, I usually give up.

22 When I listen, I recognize more words than before.

23 I have no problem listening to someone who speaks English fast.

24 I have the ability to concentrate on the content to which I listen.

25 I don't feel confident in my English listening skills.

26 I know what strategies to use when I listen to English.

27 I feel uncomfortable listening without a chance to read the transcript of the speech.

28 I'm one of the best listeners in my class.

29 If listening gets difficult for me, I am successful at fixing it up. 
30 I can concentrate more when I listen than I could before.

31 When I listen, I need less help than I used to.

32 I know what to do when I don't understand what I'm listening to.

33 When listening to English, I get nervous when I don't understand every word.

34 Listening is easier for me than it used to be.

35 My understanding of difficult listening material doesn't improve.

36 The more difficult the listening task is, the more challenging and enjoyable it is.

37 I feel good about my listening comprehension skill.

38 I am less confident in my listening skill than other students.

39 I can understand what I listen to even if I don't know several vocabulary items.

40 Lack of control over listening material isn't a problem for me.

\section{Appendix C}

Listening comprehension test

Part A: directions: In this part you will hear short conversations between two people. After each conversation, you will hear a question about the conversation. The conversations and questions will not be repeated. After you hear a question, read the four possible answers in your test book and choose the best answer.

Example:

On the recording, you hear:

(Woman) The lawyer spent hours and hours working on that case.

(Man) It's true that he prepared hard for the case, but his work was for nothing.

\section{WHAT DOES THE MAN MEAN?}

In your test book, you read:
(A) All the lawyer's work did no good.
(B) The lawyer prepared nothing for the case.
(C) It wasn't work for the lawyer to prepare for the case.
(D) The lawyer didn't work to prepare for the case.

You learn from the conversation that the woman thought the lawyer worked hard on the case and that the man thought the lawyer's work was valueless. The best answer to the question "What does the man mean?" is (A) "All the lawyer's work did no good."

Sample questions from this part:

(Man) Are you pleased with the exam results?

(Woman) I couldn't be happier.

\section{WHAT DOES THE WOMAN MEAN?}
(A) She's not very happy
(B) She didn't do very well on the exam
(C) She could be somewhat happier
(D) She's delighted with the results

(Woman) Did you enjoy the biology lecture?

(Man) The professor droned on and on about cell division.

WHAT DOES THE MAN MEAN?
(A) The professor drowned the cell in a lab
(B) The lecture was long and boring
(C) The professor divided the lecture into parts
(D) The biologist tried to sell the results of the experiment
(Woman) Did Betty listen to what her boss said?
(Man) She followed the directions to the letter.

WHAT DOES THE MAN MEAN?
(A) Betty wrote the letter as directed
(B) The directions were given to Betty in a letter
(C) Betty will follow the instructions later
(D) Betty worked exactly as instructed 
(Man) I can't find a typist to finish my term paper by tomorrow morning.

(Woman) Why not do it yourself?

WHAT DOES THE WOMAN MEAN?
(A) The man should try another type of paper
(B) The man should locate a typist tomorrow morning
(C) The man should make a tape in the morning
(D) The man should complete the paper without help

Part B: directions: In this part you will hear longer conversations. After each conversation, you will hear several questions. The conversations and questions will not be repeated. After you hear a question, read the four possible answers in your test book and choose the best answer.

Sample questions from this part:

(Narrator) Listen to a welcome address by a member of c club.

(Woman) Welcome to this introductory meeting for new members of the Sierra Club. The Sierra Club is an organization whose goals are centered on the protection of the environment. It was founded in 1892 in San Francisco by naturalist John Muir, who was intent on preserving the natural beauty and harmony of the Sierra Nevada in eastern California.

Today the Sierra Club boasts almost 200,000 members in all fifty states of the United States. Through activities such as conferences, lectures, exhibits and films, the organization works to continue the effort begun by John Muir. The Sierra Club also publishes a weekly newspaper, a bimonthly magazine, and various books.

WHAT IS THE MAIN OBJECTIVE OF THE SIERRA CLUB?
(A) To protect its members
(B) To save the natural environment
(C) To honor the memory of John Muir
(D) To improve San Francisco's natural beauty

APPROXIMATELY HOW LONG HAS THE SIERRA CLUB BEEN IN EXISTENCE?
(A) For less than a year.
(B) Only for a decade
(C) For more than a century.
(D) For at least two centuries.

WHAT AREA WAS JOHN MUIR SPECIALLY INTERESTED IN SAVING?
(A) San Francisco
(B) All fifty states
(C) The Sierra Nevadas
(D) The eastern United States

WHERE DOES THE SIERRA CLUB HAVE MEMBERS?
(A) All over the world
(B) In the entire United States
(C) Only in California
(D) Only in the Sierra Nevadas

\section{Copyrights}

Copyright for this article is retained by the author(s), with first publication rights granted to the journal.

This is an open-access article distributed under the terms and conditions of the Creative Commons Attribution license (http://creativecommons.org/licenses/by/3.0/). 